\title{
Application of Ozone and Oxygen to Reduce Chemical Oxygen Demand and Hydrogen Sulfide from a Recovered Paper Processing Plant
}

\author{
Patricia A. Terry \\ Department of Natural and Applied Sciences, University of Wisconsin-Green Bay, 2420 Nicolet Drive, ES317, Green Bay, \\ WI 54311, USA \\ Correspondence should be addressed to Patricia A. Terry, terryp@uwgb.edu
}

Received 8 January 2010; Accepted 3 May 2010

Academic Editor: Josiane Nikiema

Copyright () 2010 Patricia A. Terry. This is an open access article distributed under the Creative Commons Attribution License, which permits unrestricted use, distribution, and reproduction in any medium, provided the original work is properly cited.

A pilot study was performed at the Fox River Fiber recovered paper processing company in DePere, Wisconsin, to determine the extent to which injection of oxygen and ozone could reduce the high chemical oxygen demand, COD, in the effluent and the effectiveness of the ozone/oxygen stream in suppressing production of hydrogen sulfide gas in downstream sewage lines. Adaptive Ozone Solutions, LLC, supplied the oxygen/ozone generation and injection system. Samples were analyzed both before and after oxygen/ozone injection. Hydrogen sulfide gas was continuously monitored at sewer stations downstream of Fox River Fiber. Results showed that with a very short contact time, effluent COD was reduced by over 15\%. A simple kinetic model predicts that a contact time of fewer than 30 minutes could reduce COD by as much as $60 \%$. In addition, downstream hydrogen sulfide gas production in the sewage mains was also better controlled, such that costly Bioxide applications could be reduced.

\section{Introduction and Literature Review}

In a growing world, it is increasingly more necessary to treat municipal and industrial wastewaters using environmentally green technologies. Current technologies often employ manmade chemicals as the primary treatment agent, but there are growing concerns and problems associated with the residual effects of putting more chemicals in wastewater. Displacing these chemicals with economic, environmentally friendly processes offers a significant market opportunity [1].

Among primary manufacturing industries, paper manufacturing is the fourth largest user of energy and the largest generator of wastes, measured by weight. Water is the basic medium of pulp and paper manufacturing; it carries fibers through each treatment step and separates spent pulping chemicals and the complete mixture of organic residues from the pulp [2]. The process of pulp and paper processing involves production of effluent water streams with high chemical oxygen demand, COD, loads. COD is a measure of the oxygen requirement of the organic matter susceptible to oxidation by a strong chemical oxidant. It is used to define the organic strength of industrial wastes and polluted waters. COD wastes usually are not readily biodegradable and often contain compounds that inhibit biological activity [3] in wastewater treatment facilities.

In addition, one of the challenges faced by wastewater treatment facilities is hydrogen sulfide, $\mathrm{H}_{2} \mathrm{~S}$, gas production in sewer lines, especially in warmer weather. High biological and chemical oxygen demand loads combined with low dissolved oxygen content of sewage water and effluents from paper processing facilities create anaerobic septic conditions in sewage lines. Hydrogen sulfide gas, produced as a result of these conditions, is the most common odorous gas found in municipal wastewater collection and treatment systems. It emits a characteristic smell of rotten eggs and is both toxic to humans and corrosive to steel and concrete. Condensation moisture on the side walls and crowns of sewer pipes absorbs $\mathrm{H}_{2} \mathrm{~S}$ and oxygen from the atmosphere in the sewer and sulfur-oxidizing bacteria, Thiobacillus, then forms $\mathrm{H}_{2} \mathrm{SO}_{4}$. The sulfuric acid reacts with lime in concrete sewers causing crown corrosion and compromising the structural integrity of sewer lines $[3,4]$. 
The best protection for sanitary sewers is to use corrosion resistant pipe, such as vitrified clay or plastic, but this may be economically prohibitive in large systems. In these systems crown corrosion can be retarded by ventilation to control build-up of $\mathrm{H}_{2} \mathrm{~S}$ gas. Another treatment option is Bioxide, an aqueous solution of calcium nitrate, produced by Siemens Water Technologies, Inc. Bioxide creates a biological process that both removes dissolved $\mathrm{H}_{2} \mathrm{~S}$ and prevents its formation through the addition of nitrate oxygen. It reduces sewage treatment biological oxygen demand (BOD) loads while preventing corrosion of concrete or metal collection systems. The biggest drawbacks to Bioxide is that it adds a new chemical, calcium nitrate, to a process. Because it is still under patent protection, the biggest drawback of Bioxide is its cost, which many facilities find to be prohibitive [5].

Fox River Fiber Company, FRF, is a small recovered fiber paper manufacturing facility located in DePere, Wisconsin. The process of recovering recycled paper involves deinking by either chemical or mechanical means and creating market pulp ready for conversion to paper products. The papermaking process uses on average between 10 to 19 liters of water per kilogram of product, which includes deinking and pulping chemicals, inks, coatings, adhesives, and cellulosic and lignin paper fibers.

The Green Bay Metropolitan Sewerage District (GBMSD) wastewater treatment plant recently began accepting effluent wastewater from FRF to its DePere, WI, facility. In order to control the introduction of pollutants into the sewerage system and, ultimately, its facility, GBMSD has implemented an industrial pretreatment program to regulate certain industries called Significant Industrial Users (SIUs). SIUs must comply with federal, state, and local requirements through a permit system that includes self monitoring and compliance. GBMSD also inspects SIUs annually to review operations and promote pollution prevention. FRF because of its high effluent COD levels has been designated as an SIU.

Unlike larger paper manufacturers, Fox River Fiber Company does not pretreat its effluent water prior to discharge to the GBMSD system and, hence, must pay the sewerage district to compensate for the load associated with such high COD levels. Fox River Fiber's effluent water stream has between 5000 to $6000 \mathrm{mg} / \mathrm{L}$ CODs depending on the variety of recovered paper being processed. At its current COD release level, Fox River Fiber pays GBMSD \$1.4 million per year, $\$ 200,000$ of which is fixed and $\$ 1.2$ million of which is a linear function of the plant's effluent COD level.

In addition to high COD loads, to suppress production of hydrogen sulfide gas in sewage mains, Fox River Fiber applies as much as 1710 liters per day of Bioxide to their effluent during warm summer months when $\mathrm{H}_{2} \mathrm{~S}$ production is at its worst. Lower quantities are applied during colder months. GBMSD requires that effluent from Fox River Fiber does not lead to $\mathrm{H}_{2} \mathrm{~S}$ gas levels in the air space of the downstream sewage system that exceed a maximum peak of $40 \mathrm{ppm}$ and an average of $20 \mathrm{ppm}$ over a twenty-four hour period. The plant's normal operating temperature is about $40^{\circ}$ Celcius, which contributes to $\mathrm{H}_{2} \mathrm{~S}$ gas production and makes COD reduction more difficult.
Previous studies have considered applications of ozone to water treatment, but primarily as a disinfectant, where ozone's effectiveness is well documented $[1,3]$. Ozone is shown to reduce cryptosporidium and control taste and odor problems in surface water treatment systems [6]. Recent studies $[7,8]$ investigated ozonation to increase the biodegradation of resistant textile wastewaters containing dyes and detergents. Many commercial laundering systems have used ozone successfully and its microbiological benefits have been observed [9]. Another recent study [10] summarized potential options for improvement of wastewater treatment plant effluents using ozone and integration of ozone technology to existing and conventional plants. Preozonation has also been considered to enhance the biodegradability of recalcitrant compounds prior to biological treatment of wastewater [11]. In addition, the applicability of ozone to treatment and mass reduction of wastewater sludge has been studied [12].

A pilot study was performed on the Fox River Fiber effluent to determine to what extent COD reduction could be achieved through addition of high pressure oxygen and ozone. In addition, suppression of $\mathrm{H}_{2} \mathrm{~S}$ gas production in sewage lines was monitored. The study included reduction of Bioxide application during oxygen/ozone injection. To determine the project's success, COD was monitored in the FRF's effluent before and after oxygen/ozone injection as well as dissolved oxygen (DO), $\mathrm{pH}$, and temperature. Due to the pilot study's limitation that the ozone injection system be completely with Fox River Fiber's plant and that pre- and postinjection samples be drawn from within Fox River Fiber's facility, the contact time between injected ozone and wastewater stream was considerably less than optimal. Experiments were performed to model the kinetics of the oxygen COD degradation reaction and estimate the overall potential of the process for a longer contact time that would be included in a permanent system. A third oxygen/ozone experiment was conducted to quantify the effect of increasing ozone levels on COD removal. In addition, $\mathrm{H}_{2} \mathrm{~S}$ gas was monitored at several gravity sewage mains downstream of Fox River Fiber. While other effluent streams join the water flow to GBMSD, the temperature and COD load associated with Fox River Fiber's effluent make it the greatest contributor to low DO levels and $\mathrm{H}_{2} \mathrm{~S}$ gas production in sewage lines.

One potential concern with the use of high pressure ozone is that it is known to be corrosive to some gasket materials that are prevalent in water collection systems. UniBell PVC Pipe Association [13] has published information on resistance of natural and synthetic rubber gasket materials to ozone exposure. A number of factors must be present before ozone degradation of synthetic rubbers forms cracks that grow and lead to material failure. First, elongation must be present for crack formation. Unstretched rubber reacts with ozone until all of the surface double bonds are consumed, and then the reaction ceases. In the process, a gray film, or frosting, appears on the surface of the rubber, but no cracks form. Ozone will continue to react with rubber only if the surface of ozonized products is moved aside to expose underlying unsaturation. Consequently, cracks only form and grow if the rubber is stretched to expose underlying unsaturation. 
Because rubber gaskets in service are under a compressive load, they do not experience elongation and, hence, it is not likely that they will degrade via ozone attack past the initial inner surface of the gasket that contacts the ozonated water. The gray film, or frosting, associated with surface attack should appear, but the compressive forces holding the gasket in place should prevent the critical elongation required to expose underlying saturation. Selection of an EPDM, neoprene or Viton gasket material will also protect against loss of service due to gasket failure [14-16].

\section{Experimental Methods and Results}

Adaptive Ozone Solutions, $\mathrm{AO}_{3}$, $\mathrm{LLC}$, designed and installed the ozone system used in all pilot studies and experiments. The company, located in Lenexa, Kansas, manufactures and sells oxygen and ozone systems for municipal and industrial applications. Their patented technology uses electrochemical cells to generate ozone and supplies concentrated oxygen and ozone feed streams to wastewaters via aerosol diffusers.

Dissolved oxygen, $\mathrm{pH}$, and temperature were measured using a Hach HQ40d IntellicalTM portable field kit. COD was measured using Hach standard method 8000 photometric analysis with a Hach DRD200 reactor, Hach DR890 colorimeter, and Hach high range (0 to 15,000 ppm) plus reagent tubes. All tests were performed in triplicate with averages presented. Dissolved ozone concentration was measured with a model Q45H portable dissolved ozone analyzer from Analytical Technology, Inc. The analyzer has capability to measure dissolved ozone in the low range of $0-200 \mathrm{ppb}$ and also the range of $0-2 \mathrm{ppm}$, typical of water bottling or municipal water treatment applications.

2.1. Ozone Corrosivity. Because of the potentially corrosive nature of ozone to synthetic rubber gasket materials, tests were performed to determine how long after injection into a pipe system ozone maintains a residual. A model experimental apparatus was constructed at the Green Bay Metropolitan Sewerage District, Green Bay, Wisconsin, to measure ozone residual following injection into a stream of incoming wastewater. The system consisted of an ozone generator, ozone diffuser, and four inch PVC piping system designed by Adaptive Ozone Solutions, LLC. The generator fed ozone in an oxygen stream into the system at a rate of 18 grams/hour ozone. To measure ozone residual, nine test ports were installed into the piping system. Each of these was connected to a dissolved ozone monitor and cell.The sample ports were located at 1.5, 4.5, 10.7, 16.8, 22.9, 29.0, 50.3, 53.3, and 59.4 meters, respectively, from the diffuser.

Wastewater flow through the system was 76 liters/minute. Ozone measurements taken at the first sample port, 1.5 meters from injection, showed no residual ozone. Tests were performed multiple times to verify the zero reading. The same was the case for all downstream sample ports. For 9-centimeter outer diameter PVC pipe, a 76 liter/minute flow gives a water velocity of about $17.7 \mathrm{~cm} / \mathrm{second}$ and a residence time of 8.6 seconds to reach the 1.5 meter sample port. Therefore, the ozone residual in the water was less
TABle 1: Pre- and post- $\mathrm{O}_{2} / \mathrm{O}_{3}$ injection measurements $\left(\mathrm{O}_{3}\right.$ loading rate of $0.053 \mathrm{~g} / \mathrm{min} /$ liter water and $\mathrm{O}_{2}$ loading rate of $0.53 \mathrm{~g} / \mathrm{min} /$ liter water).

\begin{tabular}{lccccc}
\hline & $\begin{array}{c}\text { Temperature } \\
\left({ }^{\circ} \mathrm{C}\right)\end{array}$ & $\mathrm{pH}$ & $\begin{array}{c}\mathrm{DO} \\
(\mathrm{mg} / \mathrm{L})\end{array}$ & $\begin{array}{c}\mathrm{COD} \\
(\mathrm{mg} / \mathrm{L})\end{array}$ & $\begin{array}{c}\text { Standard } \\
\text { deviation }\end{array}$ \\
\hline Pre injection & 40.6 & 7.47 & 0.12 & 5244 & 352 \\
Postinjection & 40.8 & 7.31 & 18.56 & 4422 & 256 \\
\hline
\end{tabular}

than 8.6 seconds. This is similar to a result found by a study of ozone disinfection of water [1] who measured ozone residuals following disinfection with contact times of 10,18 , 50 , and 93 seconds and found that, in some cases, ozone residual decayed too rapidly to be measurable.

\subsection{Effect of Ozone and Oxygen on COD Effluent from} Fox River Fiber. For seven weeks during June through July 2009, an $\mathrm{AO}_{3}$ installed ozone generator injected 4 grams/minute of ozone, in addition to high pressure oxygen, into the approximately 76 liters/min effluent water stream of Fox River Fiber Paper Company. The ozone loading rate was $0.053 \mathrm{grams} / \mathrm{min} / \mathrm{liter}$ water and that for oxygen was $0.53 \mathrm{grams} / \mathrm{min} / \mathrm{liter}$ water. During this time, Bioxide addition was reduced incrementally from its peak application rate of 1520 liters per day to 1330 liters per day, 950 liters per day, and finally 570 liters per day. Dissolved oxygen, $\mathrm{pH}$, temperature, and COD were measured both at a sample point upstream of the injection point and one downstream of the injection point, but prior to entering the GBMSD sewage lines. Process limitations required that the postozone injection sampling point be located within the plant, such that the contact time of the oxygen/ozone stream in the system prior to the second sample point was limited to approximately two minutes. Table 1 shows the pre- and postinjection point averages for triplicate samples collected bi-weekly during the nine week pilot run.

COD in Fox River Fiber's effluent averaged $5244 \mathrm{mg} / \mathrm{L}$, while that postoxygen/ozone injection averaged $4422 \mathrm{mg} / \mathrm{L}$ for an average reduction of $15.7 \%$. The water $\mathrm{pH}$ was not significantly affected by addition of oxygen/ozone. While Bioxide addition rates were reduced during this period, COD measurements were not affected by these changes. Because of the chemicals used in the recovered paper manufacturing process, plant effluent DO was very low, but Adaptive Ozone Solution, LLC's, generator raised values to approximately $25 \mathrm{mg} / \mathrm{L}$ at the injection point and almost $20 \mathrm{mg} / \mathrm{L}$ as measured at the second sample point. Based on an average $15.7 \%$ reduction in COD and a linear relationship between the $\$ 1.2$ million per year payment made to GBMSD for excessive COD, AO3's system could save Fox River Fiber $\$ 188,400$ per year.

2.3. Kinetic Study. Because of the limitations associated with the existing piping system at Fox River Fiber, the previous COD and DO measurements were taken after a contact time of only approximately two minutes. Given an almost $16 \%$ reduction in COD for such a short reaction time, 


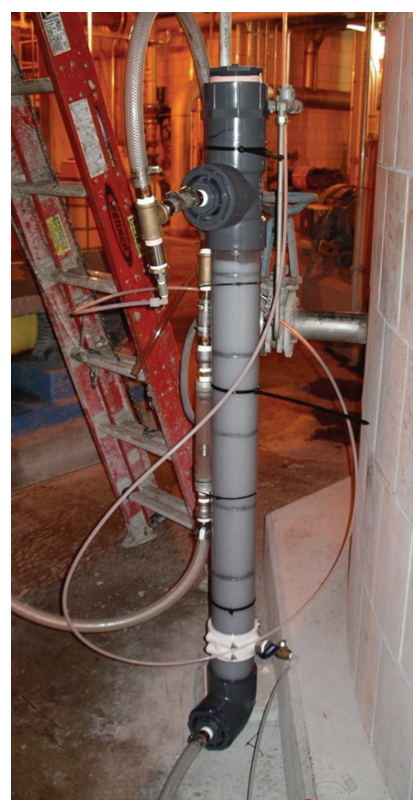

Figure 1: $\mathrm{O}_{3} / \mathrm{O}_{2}$ aerosol bubble injection contact chamber.

TABLE 2: Kinetics of first-order reaction with $k=0.12 / \mathrm{min}$.

\begin{tabular}{lcc}
\hline Time $(\mathrm{min})$ & $\mathrm{C} / \mathrm{C}_{o}$ & \% Unreacted $\mathrm{O}_{2}$ \\
\hline 1 & 0.89 & $89 \%$ \\
2 & 0.79 & $79 \%$ \\
5 & 0.55 & $55 \%$ \\
10 & 0.30 & $30 \%$ \\
20 & 0.09 & $9 \%$ \\
\hline
\end{tabular}

experiments were performed to estimate the kinetics of the reaction of oxygen with COD waste and, hence, estimate the effectiveness of oxygen and ozone to continue to reduce COD in Fox River Fiber's effluent. Dissolved oxygen was measured as a function of time in postinjection samples to estimate how rapidly oxygen is consumed by COD waste. First-order kinetics

$$
\ln \left(\frac{C}{C_{o}}\right)=-k t
$$

with respect to oxygen degradation, were assumed for the reaction

$$
\mathrm{O}_{2}+\mathrm{COD} \Longleftrightarrow \mathrm{CO}_{2}+\mathrm{H}_{2} \mathrm{O}
$$

where $C_{o}$ is initial recorded DO at the postinjection sample point, $C$ is DO remaining in water after time $t, t$ is reaction, or contact time of oxygen with COD waste, and $k$ is reaction rate constant $\left(\mathrm{min}^{-1}\right)$.

The first-order reaction rate constant was conservatively $0.12 / \mathrm{min}$. Based upon this and a reaction time between injection and the postinjection sample point of approximately two minutes, only $21 \%$ of injected oxygen was consumed prior to sampling. The COD was reduced $15.7 \%$ based upon this. Table 2 shows the percent of oxygen that would be consumed as a function of time, which would lead to lower COD

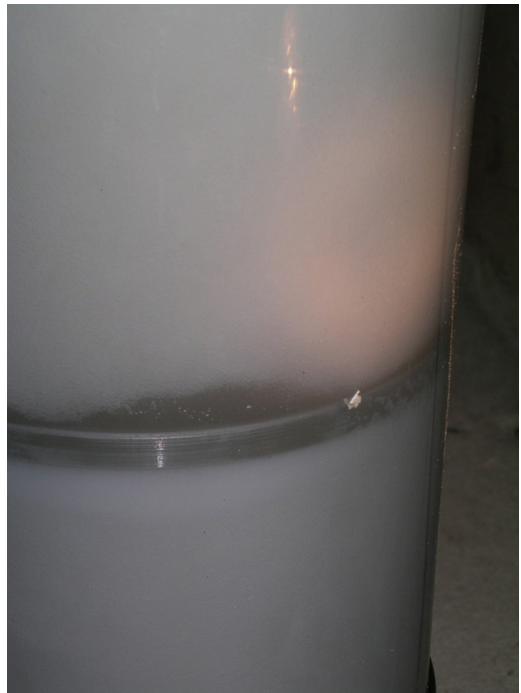

FIGURE 2: Close-up of aerosol bubble mass transfer.

TABle 3: DO and COD as a function of Ozone/Oxygen injection rate.

\begin{tabular}{lccc}
\hline $\begin{array}{l}\mathrm{O}_{3} \text { loading rate } \\
(\mathrm{g} / \mathrm{min} / \text { liter })\end{array}$ & $\begin{array}{c}\mathrm{DO} \\
(\mathrm{mg} / \mathrm{L})\end{array}$ & $\begin{array}{c}\mathrm{COD} \\
(\mathrm{mg} / \mathrm{L})\end{array}$ & \% COD reduced \\
\hline $\mathrm{No} \mathrm{O}_{2}$ or $\mathrm{O}_{3}$ & 0.14 & 5907 & \\
$0.53 \mathrm{O}_{2}$ & 67.1 & 5440 & 7.9 \\
$0.053 \mathrm{O}_{3}$ & 61.6 & 4970 & 15.8 \\
$0.105 \mathrm{O}_{3}$ & 58.5 & 5043 & 14.6 \\
$0.158 \mathrm{O}_{3}$ & 59.9 & 5040 & 14.7 \\
$0.212 \mathrm{O}_{3}$ & 62.0 & 5053 & 14.5 \\
$0.318 \mathrm{O}_{3}$ & 68.4 & 5033 & 14.8 \\
\hline
\end{tabular}

levels if the sampling point was further downstream of the injection point. While the exact reduction cannot be exactly quantified without more information about the nature of the COD waste, it is clear that actual reduction in COD sent to GBMSD would be considerably lower than that recorded from the postinjection sample point at Fox River Fiber. If a constant stoichiometric ratio of $\mathrm{O}_{2}$ to $\mathrm{COD}$ was assumed, a reaction time adequate to deplete $80 \%$ of injected oxygen could potentially remove up to $60 \%$ of COD with a reaction time of less than 20 minutes. At a linear rate of reduction in the fee paid to GBMet for excessive COD, Fox River Fiber could save $\$ 720,000$ per year.

2.4. $\mathrm{COD}$ as a Function of $\mathrm{O}_{3}$. A final experiment was performed to quantify the effect of increasing the ozone injection rate on effluent COD. A $9.5 \mathrm{liter} / \mathrm{min}$ side stream of Fox River Fiber's effluent stream was diverted and dosed with increasing quantities of ozone under the same water flow velocity and contact time as tests performed on the total effluent stream. Ozone was generated and injected with oxygen as aerosol bubbles using an $\mathrm{AO}_{3}$ system as shown in Figures 1 and 2. Initially just oxygen was added, after which both oxygen and ozone were added with the oxygen amount approximately constant at 0.53 grams $/ \mathrm{min} /$ liter water. At 
TABle 4: Peak hydrogen sulfide gas as a function of Bioxide addition at sample sites downstream of Fox River Fiber.

\begin{tabular}{|c|c|c|c|c|c|}
\hline \multirow{2}{*}{ Sample site } & \multirow{2}{*}{$\begin{array}{c}\text { Peak } \mathrm{H}_{2} \mathrm{~S}: \text { no O }_{3} \\
1520 \mathrm{~L} / \text { day }\end{array}$} & \multicolumn{4}{|c|}{ Peak $\mathrm{H}_{2} \mathrm{~S}(\mathrm{ppm})$ for each bioxide application rate with $\mathrm{O}_{3}$} \\
\hline & & $1520 \mathrm{~L} /$ day & 1330 L/day & 950 L/day & 570 L/day \\
\hline NSI035 & 3 & 3 & 2.5 & 4 & 4 \\
\hline NSI028 & 7 & 6 & 4 & 3 & 12 \\
\hline NSI013 & 6 & 1 & 0 & 9 & 22 \\
\hline ASC020 & 20 & 0 & 0 & 22 & 68 \\
\hline ASC013 & 17 & 1 & 2 & 11 & 25 \\
\hline ASC008 & 30 & 2 & 4 & 22 & 47 \\
\hline ASC005 & 9.5 & 1 & 1 & 9 & 25 \\
\hline
\end{tabular}

each ozone level, samples were drawn and analyzed for DO and COD. Table 3 summarizes the results.

The average percent reduction in COD due to ozone addition was $14.9 \%$, but increasing ozone above a loading rate of $0.053 \mathrm{grams} / \mathrm{min} / \mathrm{liter}$ water did not improve COD reduction. Addition of both oxygen and ozone did improve COD removal compared to just oxygen addition.

2.5. Hydrogen Sulfide Suppression. In addition to COD reduction, another concern of GBMSD with the high COD released by Fox River Fiber is the production of $\mathrm{H}_{2} \mathrm{~S}$ gas in gravity sewer lines between GBMSD and FRF. Both prior to and following installation of the oxygen/ozone system, continuous measurements of $\mathrm{H}_{2} \mathrm{~S}$ gas at a number of sample locations in the air space of the sewage lines were performed using Odalog gas loggers, Detection Instruments Corporation, in the 0 to $200 \mathrm{ppm}$ range. The first set of data was collected between 6/2/2009 to 6/25/2009. During the first week of June, 2009, Green Bay experienced record high temperatures which would increase $\mathrm{H}_{2} \mathrm{~S}$ gas production. Table 4 summarizes the results. Dissolved sulfides in the liquid phase were also measured and varied between 0 and $0.5 \mathrm{ppm}$.

At the beginning of the study Bioxide was added to the system by FRF at a rate of 1520 liters per day. Almost immediately Bioxide was reduced to 1330 liters per day. Within 24 hours, it was reduced to 950 liters per day. After eight days Bioxide was further reduced to 570 liters per day. For all tests, the $\mathrm{O}_{3}$ loading rate was 0.053 grams $/ \mathrm{min} / \mathrm{liter}$ water, and the $\mathrm{O}_{2}$ loading rate was $0.53 \mathrm{grams} / \mathrm{min} / \mathrm{liter}$ water.

A comparison of peak $\mathrm{H}_{2} \mathrm{~S}$ data in Table 4 for the cases of just 1520 liters/day Bioxide and 1520 liters/day Bioxide with ozone/oxygen generation shows that additional of ozone/oxygen to the FRF effluent did reduce the peak $\mathrm{H}_{2} \mathrm{~S}$. Reducing the Bioxide addition to 1330 liters/day and 950 liters/day did not result in increased $\mathrm{H}_{2} \mathrm{~S}$ peak values, and average values were consistently below $20 \mathrm{ppm}$. For all sample sites, peak $\mathrm{H}_{2} \mathrm{~S}$ remained below the maximum acceptable upper limit of $40 \mathrm{ppm}$. In addition, average $\mathrm{H}_{2} \mathrm{~S}$ remained below the required $20 \mathrm{ppm}$ for all but one measurement. Further reducing Bioxide to $150 \mathrm{gal} /$ day resulted in two $\mathrm{H}_{2} \mathrm{~S}$ peaks that exceeded the acceptable upper limit and many averages above $20 \mathrm{ppm}$. The optimal Bioxide dose could be as low as 780 liters/day, which would save FRF up to 780 liters/day during warmer summer months. Even at a reduced dose of 950 liters/day, $150 \mathrm{gal} /$ day of Bioxide could be saved. At a cost of $\$ 0.695$ per liter, $\$ 396 /$ day could be saved.

\section{Conclusions}

Addition of a high pressure oxygen/ozone stream to the effluent discharged by Fox River Fiber Company to the GBMSD system reduced COD sent to GBMSD by FRF by over $15 \%$ despite a very small contact time. A first-order kinetic model of the degradation reaction between oxygen and COD predicts as great as a 60\% COD reduction if the contact time was increased via additional piping to as few as 30 minutes. Dissolved oxygen in the system was greatly increased by the Adaptive Ozone Solutions process. FRF currently pays a fee of $\$ 1.2$ million per year to GBMSD to handle their high COD stream, but this fee is linearly proportional to average COD. A $15.7 \%$ reduction, therefore, could save FRF $\$ 188,400$ annually. A $60 \%$ reduction in effluent COD could save the plant as much as $\$ 720,000$ annually. While this analysis did not include the electrical cost of the ozone generator, this amount would be small (on the order of several hundred dollars per month) compared to the potential savings.

Hydrogen sulfide gas monitoring during the study showed that the Adaptive Ozone Solutions, LLC, process could suppress $\mathrm{H}_{2} \mathrm{~S}$ gas production in the air space of the sewage mains to below peaks of $40 \mathrm{ppm}$, the maximum acceptable value, under reduced Bioxide applications. Data showed that reducing Bioxide to 950 liters per day maintained sufficiently low hydrogen sulfide production, but that further decreasing the Bioxide addition rate to 570 liters per day caused two peaks above $40 \mathrm{ppm}$. Additional experimentation would be required to determine the exact point between 570 and 950 liters per day at which hydrogen sulfide peaks would become unacceptably high. This particular sewage system used gravity mains, which allows discharge of residual injected oxygen. It is anticipated that hydrogen sulfide production would be even more effectively suppressed in a force main, which operates under pressure. A reduction of 150 gallons per day would save FRF $\$ 144,540$ per year based on 365 days per year operation. A reduction to as little as 780 liters per day could save $\$ 192,720$ annually. Hence, at the experimental conditions employed during the summer 
trial, FRF could save as much as $\$ 332,940$ in cost of high CODs and reduced Bioxide. If the contact time between injected oxygen and COD was increased prior to the effluent leaving the plant Bioxide could be reduced by as much as 950 gallons per day, a maximum potential savings of $\$ 960,900$ annually.

\section{References}

[1] C. Ishida, A. Salveson, K. Robinson, R. Bowman, and S. Snyder, "Ozone disinfection with the HiPOX reactor: streamlining an "old technology" for wastewater reuse," Carollo Engineers, Applied Process Technology and Southern Nevada Water Authority, 2007.

[2] Paper Task Force: Duke University, Environmental Defense Fund, Johnson and Johnson, McDonalds, Prudential Insurance Company of America, Time Inc., Pulp and Paper Manufacturing, pp. 170-176, December 1995.

[3] W. Viessman, J. Hammer, E. Perez, and Chadik P., Water Supply and Pollution Control, Pearson Publishing, 8th edition, 2009.

[4] W. D. Callister, Materials Science and Engineering: An Introduction, John Wiley and Sons, New York, NY, USA, 4th edition, 1997.

[5] http://www.wef.org.

[6] D. E. Phares, D. M. Rokjer, I. A. Crossley, and J. J. Franko, "Modeling and validating the effective hydraulic detention time for a 10 mgd ozone contactor at the lake Washington surface water treatment plant, Melbourne, Florida," Ozone Science and Engineering, vol. 31, no. 3, pp. 262-276, 2009.

[7] J. Perkowski, L. Kos, and S. Ledakowicz, "Application of ozone in textile wastewater treatment," Ozone Science and Engineering, vol. 18, no. 1, pp. 73-85, 1996.

[8] N. Takahashi and T. Kumagai, "Application of ozonation to dyeing wastewater treatment-case study in Nishiwaki treatment plant," Ozone Science and Engineering, vol. 30, no. 6, pp. 439-446, 2008.

[9] R. G. Rice, M. DeBrum, D. Cardis, and C. Tapp, "The ozone laundry handbook: a comprehensive guide for the proper application of ozone in the commercial laundry industry," Ozone Science and Engineering, vol. 31, no. 5, pp. 339-347, 2009.

[10] A. Ried, J. Mielcke, and A. Wieland, "The potential use of ozone in municipal wastewater," Ozone Science and Engineering, vol. 31, no. 6, pp. 415-421, 2009.

[11] J. Van Leeuwen, A. Sridhar, A. K. Harrata et al., "Improving the biodegradation of organic pollutants with ozonation during biological wastewater treatment," Ozone Science and Engineering, vol. 31, no. 2, pp. 63-70, 2009.

[12] E. E. Richardson, A. Hanson, and J. Hernandez, "Ozonation of continuous-flow activated sludge for reduction of waste solids," Ozone Science and Engineering, vol. 31, no. 3, pp. 247256, 2009.

[13] Uni-Bell PVC Pipe Association, Handbook of PVC Pipe Chapter 3: Resistance to Aggressive Environments, Uni-Bell Pipe Association, 2001.

[14] R. W. Layer and R. P. Lattimer, "Protection of rubber against ozone," Rubber Chemistry and Technology, vol. 63, pp. 426445,1990

[15] G. Meijers and P. Gijsman, "Influence of environmental concentrations of ozone on thermo-oxidative degradation of PP," Polymer Degradation and Stability, vol. 74, no. 2, pp. 387391, 2001.
[16] S. Rahman, "Sealing our buried lifelines: understanding how rubber gaskets are designed to function in municipal pipe joints is critical to sound decision making in the field," American Water Works Association, pp. 12-17, April 2007, http://www.awwa.org/communications/opflow. 

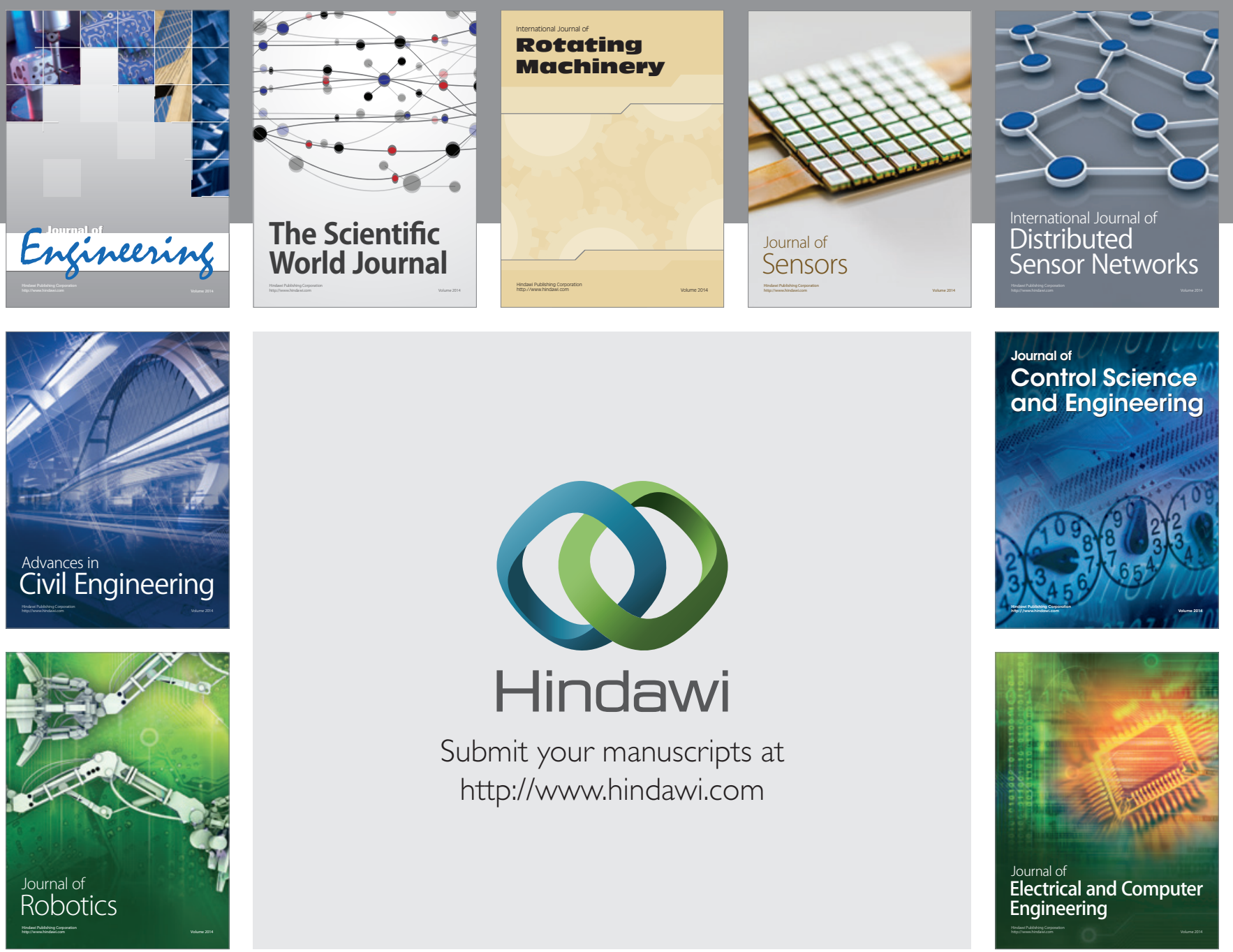

Submit your manuscripts at

http://www.hindawi.com
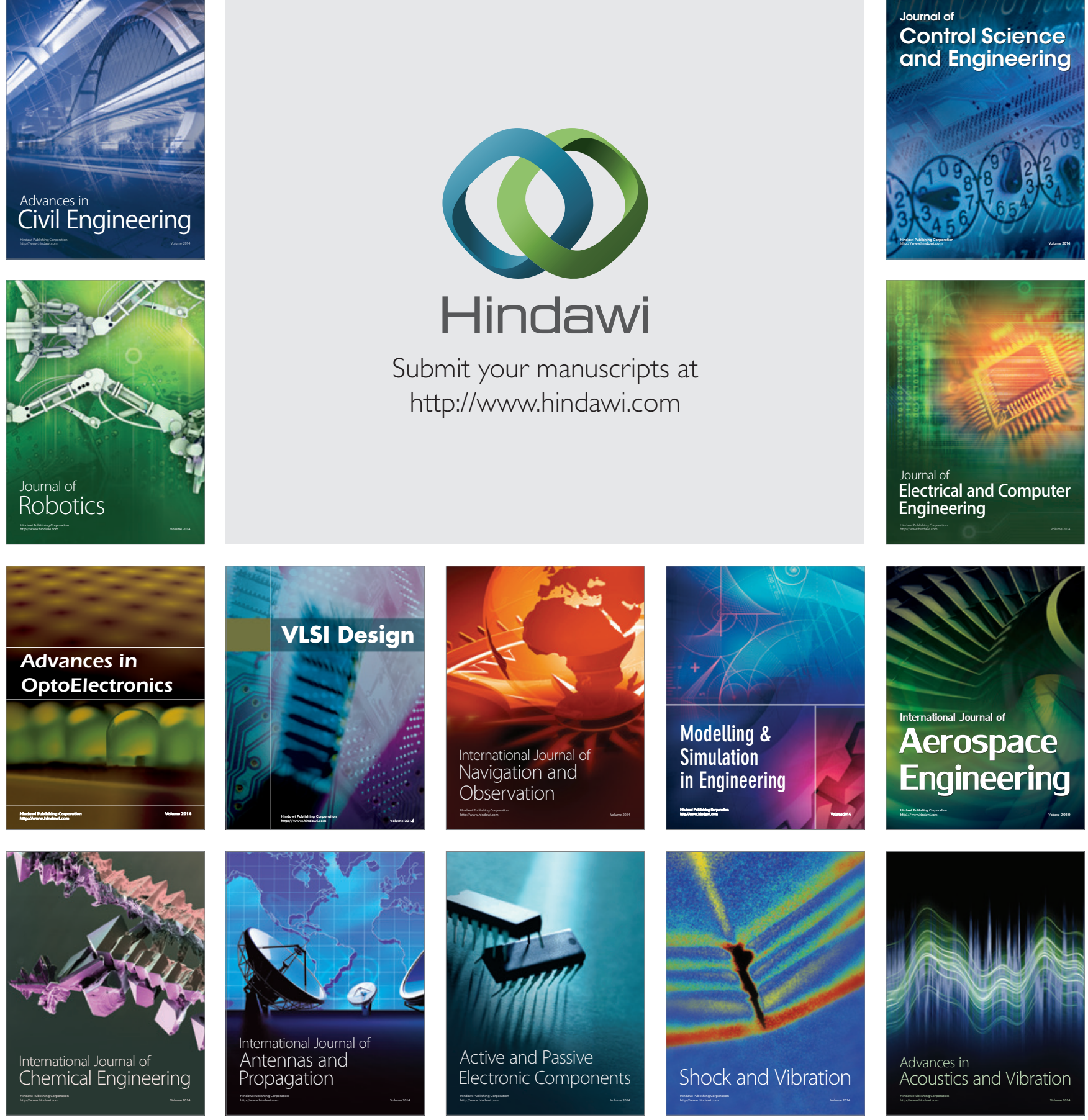